\title{
Mutations in the GNAS Gene Prevent the Cell Invasion by Activating the MEG3/Wnt/ $\beta$-catenin Axia in Growth Hormone-secreting Pituitary Adenoma
}

Chao Tang

Medical School of Nanjing University

Chunyu Zhong

Children's Hospital of Nanjing Medical University

Junhao Zhu

Medical School of Nanjing University

Feng Yuan

Medical School of Nanjing University

Jin Yang

Medical School of Nanjing University

Xiangming Cai

Southeast University

Yong Xu

Jiangsu Cancer Hospital \& Jiangsu Institute of Cancer Research \& the Affiliated Cancer Hospital of Nanjing Medical University

Chiyuan Ma (D machiyuan_nju@126.com )

Medical School of Nanjing University

\section{Research Article}

Keywords: GHPAs, GNAS mutation, MEG3, $\beta$-catenin, EMT

Posted Date: April 6th, 2022

DOI: https://doi.org/10.21203/rs.3.rs-1173994/v2

License: (1) This work is licensed under a Creative Commons Attribution 4.0 International License. Read Full License 


\section{Abstract}

Approximately $30-40 \%$ of growth hormone-secreting pituitary adenoma (GHPA) harbor somatic mutations in the GNAS (a subunit of the stimulatory G protein) gene. However, the latent functional role of the mutations and relative molecular mechanism in GHPA remain unknown. The GNAS gene mutations were detected in GHPAs using a standard PCR-sequencing procedure. The mutation-associated MEG3 expression was measured by RT-qPCR. MEG3 was manipulated in GH3 cells using a lentiviral expression system. Alterations in mRNA profiles in the MEG3-overexpressed cells were analyzed by RNA-seq. The cell invasion ability was measured using a Transwell assay, and the EMT-associated proteins were quantified by immunofluorescence and western blot. Finally, a tumor cell xenograft mouse model was applied to verify the effect of $M E G 3$ on tumor growth and invasiveness. The percentage of invasive tumors was significantly declined in GNAS-mutated GHPA tumors with the GNAS mutations compared to those tumors with the wild-type of GNAS. Consistently, the GH3 cell invasion capacity was decreased by expressing the mutant GNAS. MEG3 is uniquely expressed at high levels in GHPA harboring the mutated GNAS gene. Accordingly, the upregulation of MEG3 resulted in inhibiting cell invasion; and vice versa, the downregulation of MEG3 led to enhancing cell invasion. Mechanistically, the high level of MEG3 in mutated GNAS cells prevented the cell invasion via inactivation of the $W n t / \beta$-catenin signaling pathway, which was further validated in vivo. The GNAS mutations inhibit the invasiveness of GHPA cells via inactivation of the MEG3/Wnt/ $\beta$-catenin signaling pathway.

\section{Introduction}

Growth hormone-secreting pituitary adenoma (GHPA)accounts for $12.5 \%$ of pituitary neuroendocrine tumors, and excessive growth hormone resulted in acromegaly and systemic complications(Orme et al., 1998,Colao et al., 2004,Melmed, 2006).Acromegaly has been associated with a two-fold increase in mortality, mainly due to cardiovascular disease, which can be reversed by treatments for controlling the hormone over-production(Melmed, 2006). In addition, approximately half of patients with GHPA experienced high-risk relapse after the surgical reduction due to tumor cells infiltrating the surrounding tissues. Thus, supplementary chemotherapy still needs to control the tumor recurrence(Wilson et al., 2013).

It has been well-demonstrated that mutations found in the GNASgene, encoding a subunit of the stimulatory G protein, were detected in around $40 \%$ of GHPA(Goto et al., 2014,Hayward et al., 2001). The functional studies suggested that the GNAS mutations lead to the constitutive activation of adenylyl cyclase (AC), thereby inducing the cyclic AMP (CAMP) signaling pathway in pituitary tumors(Lania et al., 2012,Mantovani et al., 2010). The function of the GNAS mutations is thought to be involved in cell proliferation and hormone secretion(Stork and Schmitt, 2002).

Maternally expressed gene 3 (MEG3), a large non-coding RNA (IncRNA), was first identified as a tumor suppressor in the pituitary(Zhang et al., 2003). The function of MEG3is associated with inhibition of cell invasion(Ma et al., 2019). In addition, the cAMP response element (CRE), located at the MEG3proximal 
promoter region, is critical for MEG3expression(Zhao et al., 2006). Furthermore, cyclic adenosine monophosphate-responsive element-binding protein (CREB), as a downstream target of mutated GNAS, is also implicated in upregulation of MEG3by binding to the CRE site(Zhao et al., 2006,Yamamoto et al., 1990). Therefore, we speculate that the GNAS mutations may participate in the upregulation of MEG3 expression. The present study aimed to ascertain whether the GNAS mutation inhibits theinvasiveness of GHPA cells mainly through MEG3-mediated inactivation ofthe $W n t / \beta$-catenin pathway, which may provide a new therapeutic approach for treating GHPA.

\section{Materials And Methods}

\section{Patients and clinical characteristics.}

Tumor samples were collected fromforty-fourpatients with acromegaly who underwent endoscopic endonasal transsphenoidal surgery at the Department of Neurosurgery of Nanjing Jinling Hospital (Nanjing, China) between Nov. 2018 and Nov. 2019, including 21 males and 23 females. Additionally, 10 patients with clinically non-functioning pituitary tumors (NFPA) were included as negative controls. Approval for the study was obtained from the Ethical Committee of Nanjing Jinling Hospital (2018NZKY008-02) and informed consents were obtained from all the patients who participated in this study. Pituitary adenomas were classified into invasive and non-invasive tumors, according to the degree of lateral extension to the cavernous sinus (CS) space by MRI scanning(Cottier et al., 2000). Knosp grade 3 and 4 were defined as invasive pituitary adenomas, and Knosp grade 0 to 2 were defined as non-invasive tumors, respectively(Knosp et al., 1993). Tumor volume was determined by (length $\mathrm{x}$ width $\mathrm{x}$ height $\mathrm{x}$ п)/6. The clinical characteristics of patients were described in Table 1.

\section{Detection of mutationsin theGNAS gene}

Genomic DNA was extracted from 44 GHPA and 10 NFPA tissues using a DNA miniprep kit according to the manufacturer's protocol (Qiagen $\mathrm{GmbH}$, Hilden, Germany). The underlying point mutations in the GNAS gene have been reported in tumor specimens were CGT-to-TGT mutation at codon 201 (Arg201Cys) and CAG-to-CTG mutation at codon 227 (GIn227Leu) (Goto et al., 2014). PCR amplification of codon 201 and 227 was performed using a Taq DNA-Polymerase (TTH Biotools Madrid, Spain) as previously described(Goto et al., 2014). The PCR products were purified by a PCR purification kit (Qiagen $\mathrm{GmbH}$ ), and then directly sequenced by an ABI3730XL analyzer (Applied Biosystems, Thermo Fisher Scientific, Inc., Carlsbad, USA). The primer sequences from PCR and DNA sequencing were listed in Table 2.

\section{Cell culture and transduction}

$\mathrm{GH} 3$, a rat $\mathrm{GH}$-secreting pituitary tumor cell line, which produces both growth hormone and prolactin, was purchased from the Cell Culture Centre, Institute of Basic Medical Sciences, Chinese Academy of Medical Sciences (Beijing, China). GH3 cells were cultured in Ham's F12 mediumsupplemented with 10\% FBS and $1 \%$ streptomycin and penicillin in a humidified $5 \% \mathrm{CO}_{2}$ incubator at $37^{\circ} \mathrm{C}$. 
A pWPT lentiviral expression vector was used to clone the wild-type or mutant-type GNAS gene and the generated construct was termed as follows: pWPT-GNAS (expressing GNAS wild-type), pWPT-GNASQ227L (expressing the mutated GNAS at Q227L), and pWPT-GNAS-R201C(expressing the mutated GNAS at R201C), respectively. GH3 cells were plated in 6-well plates at 70\% confluence and then injected with lentivirus to express the wild-type or mutant-type GNAS.

\section{RNA extraction and quantitative reverse transcription PCR (RT-qPCR)}

Total RNAs were isolated from tissues or cells using Trizol reagent and reverse transcribed into complementary DNA (cDNA) using the TaqMan MicroRNA Reverse Transcription Kit (TaKaRa, Dalian, China). RT-qPCR was performed using an SYBR Green PCR Master Mix (Takara, Japan) according to the manufacturer's instructions. The sequences of qPCR primers were listed in Table 2. The IncRNA MEG3 was normalized by $\beta$-actin and the level of MEG3 in GHPA was further normalized by its level in NFPA.

\section{RNA-seq}

Total RNA was qualified by Agilent 2100 Bioanalyzer (Agilent Technologies, Palo Alto, CA, USA), and the next-generation sequencing library was prepared according to the protocol provided by the manufacturer (NEBNext ${ }^{\circledR}$ Ultra ${ }^{\text {TM }}$ RNA Library Prep Kit for Illumina ${ }^{\circledR}$ HiSeq system). The sequences and data analysis were performed by Genewiz, China.

\section{Western blots}

Proteins were extracted from tumor cells and tissues within RIPA buffer (Beyotime Biotech., Shanghai, China), and separated in SDS-Page gels and transferred onto polyvinylidene fluoride membranes. After blocking with $5 \%$ fat-free milk in a Tris-buffered saline with $0.1 \%$ Tween 20 , the membranes were incubated at $4^{\circ} \mathrm{C}$ overnight with the primary antibodies against MMP-2, $\beta$-catenin, MMP-9, and $\beta$-actin, which were purchased from Cell Signaling Tech., Danvers, MA, USA). Subsequently, the membranes were incubated with horseradish peroxidase-conjugated secondary antibody (Cell Signaling Tech.). The images were visualized using enhanced chemiluminescence (Beyotime). Pierce ECL Western Blotting Substrate (Thermo Scientific) was used to detect the chemiluminescence signals. Densitometric analyses of the western blot bands were performed using the Bio-Rad Imaging system (Bio-Rad, Hercules, California, USA).

\section{Transwell assay}

Matrigel matrix diluent $(300 \mu \mathrm{g} / \mathrm{mL})$ was used to coat the bottom of the upper chamber of the Transwell chamber and in a pre-cooled environment at $4^{\circ} \mathrm{C}$. The volume ratio of serum-free $\mathrm{F} 12$ medium to matrigel in the upper chamber was $4: 1$, the total volume was $100 \mu \mathrm{l}$, and the matrigel was frozen overnight at $4{ }^{\circ} \mathrm{C}$. The next day, $500 \mu \mathrm{l}$ of F12 medium containing 10\% FBS was added into the lower chamber. Cells $\left(1 \times 10^{5}\right)$ were seeded in the upper chamber. After incubation for $48 \mathrm{~h}$, non-invading cells in the upper chamber were removed. Cells that invaded the bottom chamber were fixed with $4 \%$ paraformaldehyde 
and stained using $0.1 \%$ crystal violet (Beyotime). Five random fields were selected for counting purposes under a microscope (magnification, $\times 200$ ).

\section{Immunofluorescence}

Tumor tissue sections from surgical resection of GHPA. Tissue slides were fixed with $4 \%$ formaldehyde, blocked using $10 \%$ normal goat serum. Primary antibodies against $\beta$-catenin, E-cadherin, $\mathrm{N}$-cadherin, Vimentin were diluted at 1:100 in PBS and added to the slides. All the antibodies were obtained from Cell Signaling Technology. After incubation overnight at $4^{\circ} \mathrm{C}$. After removal from the incubation chamber, slides were washed thrice with PBST. Then sections were incubated for 40 minutes in the dark in a humidified chamber at room temperature with goat polyclonal secondary antibody to rabbit IgG (1:300, Abcam Biotechnology, USA) reconstituted in PBS. Sections were washed three times with PBST. After the counterstaining procedure, sections were treated with glycerol/PBS (2:1) for 10 minutes in the dark at room temperature. counted in five randomly chosen fields using an Axiovert 200 fluorescent microscope.

\section{Subcutaneous xenografts in nude mice}

The animal experiments were approved by the Animal Experimentation Ethics Committee of the Jinling Hospital of Nanjing University.

Four-week-old female athymic BALB/c nude mice were purchased from the Shanghai SLAC Laboratory Animal Co. Ltd (Shanghai, China) and were housed and maintained in laminar airflow chambers under specific pathogen-free conditions. GH3 cells with different levels of MEG3 $\left(10^{7}\right.$ cells $\left./ 0.1 \mathrm{ml}\right)$ were subcutaneously injected into the right back side of mice. One week after the injection. After the tumor formed, lithium chloride ( $60 \mathrm{mg} / \mathrm{kg} / \mathrm{d}$ in $100 \mu \mathrm{l}$ saline), a $\beta$-catenin activator, was administered daily by intraperitoneal injecting in the group with the high levels of MEG3. The other groups were injected with saline alone as the controls. Tumor volumes were measured with a vernier caliper twice a week and calculated as (length $\times$ width ${ }^{2}$ )/2. Four weeks after injection, the mice were sacrificed by cervical dislocation, and dissected tumors were weighed and processed to determine the expression levels of the relative proteins, including $\beta$-catenin, E-cadherin, N-cadherin, MMP-2, MMP-9.

\section{Immunohistochemistry (IHC)}

Tumor tissues from mice were fixed and antigens were exposed via heat-induced epitope retrieval with exposure to citric acid buffer ( $\mathrm{pH}=7.0)$, blocked in $10 \%$ normal goat serum, and incubated with $3 \%$ hydrogen peroxide. The tissue slides were incubated with the primary antibodies against $\beta$-catenin (1:200), E-cadherin (1:200), N-cadherin (1:200), MMP-2 (1:200), MMP-9 (1:200) overnight at $4^{\circ} \mathrm{C}$, and then followed by incubated with a goat anti-rabbit secondary antibody (Beyotime) for $15 \mathrm{~min}$ at $37^{\circ} \mathrm{C}$. The number of the positive cells was subsequently counted in each section in 10 random microscope fields (magnification, x200).

\section{Statistical analysis}


Statistical data analysis was done using SPSS 19.0. The Student's unpaired T-test and Fisher's exact test were used for intergroup analysis. The results were presented as mean \pm standard deviation and the correlation was analyzed using a Spearman's correlation. $\mathrm{P}<0.05$ was considered as statistical significance.

\section{Results}

\section{The GNAS mutations are collected toGHPA}

Total 44 patients with GHPA and 10 patients with NFPA were enrolled in this study. The GNAS mutations were scanned by directly sequencing the genomic PCR products amplified from the patient's tumor sampleswith the specific primer sets. The results showed 16 out of the 44 cases carrythe GNAS mutations, including 8 cases in codon 227 but other 8 cases in codon 201. In contrast, noGNAS mutation was detected in all 10 NFPA patients.Subsequently, the patients were divided into two groups (GNAS-WT, $\mathrm{n}=28$, GNAS-MUT, $\mathrm{n}=16$ ). Compared to the GNAS-WT group, the tumor volumes were significantly reduced in the GNAS-MUT group. Additionally, the percentage of invasive tumors (Knosp grade 3-4) in the GNASMUT tumors was also remarkably decreased (Table 1). There were no statistical differences in age or gender between the two groups.

\section{The mutant GNASleads to inhibiting the GH3 cell invasion}

The results from our clinical analysis predicted that the GNAS mutationsare associated with the invasiveness of GHPA. Accordingly, GH3 cells expressed the wild-type or the mutant-type of GNAS were constructed. The cellswere injected with lentivirus carrying Flag-tagged Q227L(pWPT-GNAS-Q227L) or R201C (pWPT-GNAS-R201C), as well as GNAS-WTcontrol (pWPT-GNAS)(Fig. 1A). Furthermore,the cell invasion capacitywas significantly decreased inGH3-Q227L and GH3-R201C cellscompared toGH3-GNASWTcells(Fig. 1B).In addition, the expression levels of MMP-2 and MMP-9 inGH3-Q227L and GH3-R201C cellswere apparently reduced as well (Fig. 1C).

\section{The mutant GNAS upregulatesMEG3expression}

It was speculated that the GNAS mutations may participate in the upregulation of MEG3 expression. To verify the prediction, the expression levels of MEG3 in NFPA and GHPA tumor tissues were quantified by RT-qPCR.As expected,the levels of MEG3 strikingly increase in 44 GHPA tumor tissues compared to 10 NFPA tumor tissues (Fig. 2A).Intriguingly,MEG3 expression further highly increases in the 16 GHPA tumor tissues with mutant GNAS compared to 28 wild-type tumors (Fig. 2B). Consistently, the high levels of MEG3 were verified in the GHPA tumor tissues with a single mutant site atQ227L and R201C, respectively(Fig. 2C).Importantly,tumor invasiveness was significantly declined in the high level of MEG3group compared to the low level of the MEG3 group (Fig. 2D), suggesting that MEG3 may negatively correlation with tumor cell invasion in theGHPAs.

\section{MEG3inhibits the invasiveness of GH3 cells}


To verify if $M E G 3$ is able to inhibit cell invasion, MEG3 was manipulated using lentiviral expression systems, either ectopically expressed or knocked down in GH3 cells. After lentivirus infection the cells, MEG3 was quantified byimmunofluorescenceand RT-qPCR (Fig. 3A).Expectedly,compared tolentiviral vector control, theoverexpression of MEG3 resulted in decreasing cell invasion. In contrast, the silence of MEG3 led to increased cell invasion (Fig. 3B). Consistently, the protein expression levels ofMMP-2 and MMP-9 were decreased inMEG3-overexpressed cells, while their levels increased in MEG3-silenced cells(Fig $3 \mathrm{C}$ ). These results suggest that the GNAS mutations inhibit the invasiveness of GHPA tumors partially through activating MEG3.

\section{MEG3inhibits cell invasion via inactivating the $W n t / \beta$-catenin signaling pathway}

To further investigate the mechanism by which MEG3 inhibits GHPA cell invasion, MEG3 was overexpressed in GH3 cells and the RNA expression profile was analyzed by RNA-seq. The results revealed that the $W n t / \beta$-catenin signaling pathway is potential in the involvement of cell invasion regulation (Fig. 4A). Consistently, The mRNA level of $\beta$-catenin significantly decreased in $\mathrm{GH} 3$ cells with the GNAS mutations. Ectopic expression of $M E G 3$ in $\mathrm{GH} 3$ cellsresulted in reducing $\beta$-catenin expression, conversely, the silence of MEG3 inGH3 cellsled to increasing the level of $\beta$-catenin (Fig. 4B and C). Likewise,the level of $\beta$-catenin inGHPAtumors carrying theGNAS mutations was apparently lower than that in wild-type tumors, which was associated with the high level of MEG3 (Fig. 4D and E). The results suggested that MEG3 negatively regulates $\beta$-cateninand promotes cell invasion, particularly inGHPA cells carrying the GNAS mutations.

\section{Inactivation of $\beta$-catenin suppresses theGHPA cellinvasion}

Licl and Dickkopf1 (Dkk1) have been identified as an activator and a suppressor of $\beta$-catenin, respectively(Niehrs, 2006,Gupta et al., 2012). Accordingly, MEG3-overexpressed cells were treated with 20 $\mathrm{mM}$ of Licl (Zhang et al., 2019), and MEG3-si cells were treated with $150 \mathrm{ng} / \mathrm{ml}$ Dkk1 (Zhuang et al., 2017). As expected, $\beta$-catenin expression was increased in the Licl-treated cells but decreased in the Dkk1-treated cells (Fig. 5A). In addition, the Licl treatment enhanced the cell invasion, but the Dkk1 treatment inhibited the cell invasion (Fig. 5B). Furthermore, Liclwas able to upregulate the expression levels of MMP-2 and MMP-9. In contrast, Dkk1 was capable to suppress MMP-2 and MMP-9 expression(Fig. $5 \mathrm{C}$ ). These results suggest that MEG3 suppresses GHPA cell invasion by inhibiting the $\beta$ catenin-activated.

\section{The GNAS mutations inhibitthe epithelial-to-mesenchymal transition (EMT) process}

EMT is widely recognized to play a fundamental role in the promotion of cell mobility and tumor metastasis and the $W n t / \beta$-catenin signaling pathway is a key mechanism underlyingEMT(Li et al., 2019 ,Ghahhari and Babashah, 2015).To reveal the effect of the GNASmutations on the EMT process, the expression of $\beta$-catenin regulated EMT-associated proteins was quantified by immunofluorescence, such $\mathrm{E}$-cadherin as a cell adherent marker, $\mathrm{N}$-cadherin and Vimentin as mesenchymal markers. The results showed that E-cadherin increased but $\mathrm{N}$-cadherin and Vimentin decreased inGHPA tumors carrying 
the GNAS mutations and the high constitutive levels of MEG3, as compared to the wild-type of GHPA tumors(Fig. 6A and B). Altogether, our finding suggests that the GNAS mutations inhibit the invasiveness of GHPA via downregulation of EMT, as illustrated in Fig. 6C.

\section{MEG3inhibiting the cell invasion was validated in vivo}

To further verify that MEG3 suppresses the GHPA cell invasion by inhibiting $\beta$-catenin-regulated EMT, $\beta$ catenin was manipulated by overexpressing MEG3 in $\mathrm{GH} 3$ cells and then treating withLicl. The cells were subcutaneously injected into nude mice for tumor formation. Compared to the control group injected with $\mathrm{GH} 3$ cells, the tumor volume and weight were reduced inMEG3-overexpressed cells, but dramatically increased byLicl, indicating thatLiclsufficiently abrogated the negative effect of MEG3 in the regulation of $\beta$-catenin (Fig. 7A-C).Consistent with the regulated levels of $\beta$-catenin in the formed tumors, E-cadherin increased by overexpressing MEG3, but further decreased by treating withLicl.In contrast, the expression levels of N-cadherin, $\beta$-catenin, MMP-2 and MMP-9 decreased by elevating MEG3 and increased byLiclmediated induction (Fig. 7D and E). The results confirmed that MEG3 negatively regulates EMT via downregulating $\beta$-catenin.

\section{Discussion}

GHPA is a typically benign tumor with a high incidence and large economic burden and often manifests with invasive growth (Katznelson et al., 2014). Numerous studies indicated that the presence of the paradoxical GNAS point mutations strongly reflects the biological characteristics of GHPAs, such as a tendency for densely granulated tumors and smaller tumor size (Landis et al., 1990, Spada et al., 1990, Spada et al., 1991). A previous study has suggested that Gsa protein encoded by the GNAS gene is a key for activating the cAMP-dependent pathway in pituitary cells for differentiation and proliferation (Billestrup et al., 1986). However, the potential role and explicit mechanism of GNAS gene mutation in the invasiveness of GHPAs remains to be fully elucidated. In this regard, the finding from this study indicated that the incidence of invasiveness was markedly reduced in GHPA tumors carrying the GNAS mutations, compared to the wild-type of GNAS. Furthermore, GH3 cells possessing Q227L or R201C mutation appeared a lower percentage of invasive cells in comparison with the corresponding wild-type control cells. Thus, it is speculated that GNASgene mutations inhibit the invasiveness of GHPA cells.

The GNAS mutations have been proposed to involve the constitutive activation of cAMP formation, which plays a causal role in pituitary adenomas (Mantovani et al., 2010). Interestingly, MEG3 was identified as a tumor suppressor that is a downstream target of cAMP (Zhao et al., 2006, Zhang et al., 2010, Ma et al., 2019). The previous evidence indicated that the level of MEG3 is uniquely high in GHPA, but not in NFPAs (Gejman et al., 2008). Thus, we have speculated that the GNAS mutations suppress the invasiveness of GHPA mainly through activating MEG3. As expected, the high levels of MEG3 were only detected in GHPA tumors carrying the GNAS mutations. The MEG3 levels were also significantly increased in $\mathrm{GH} 3$ cells expressing GNAS gene mutations, compared to the cell expressing the wild-type of GNAS gene, suggesting that the GNAS mutations inhibit the GHPA cell invasion through MEG3 activation. 
Furthermore, to ascertain that the effect of MEG3 in cell invasion, we manipulated MEG3 in GH3 cells. Ectopic expression of $M E G 3$ resulted in reducing the cell invasion, and vice versa, the silence of $M E G 3$ led to enhancing the invasiveness. Altogether, our results suggest that MEG3 plays an important role in the promotion of GHPA invasiveness.

The canonical $W n t / \beta$-catenin signaling pathway is thought to be a key regulator in the EMT process and tumor progression (Krishnamurthy and Kurzrock, 2018). Upon activation of the Wnt pathway, $\beta$-catenin accumulates in nuclei and functions as a factor (Nusse and Clevers, 2017). In the present study, we showed that the GNAS mutations lead to an increase of MEG3 but a decrease of $\beta$-catenin. Furthermore, the activation of $\beta$-catenin by Licl enhanced the cell invasion and the inactivation of $\beta$-catenin by Dkk1 inhibited the cell invasion. Subsequently, Elevated MEG3 leads to downregulation of $\beta$-catenin in GHPA

cells. In parallel, the silence of MEG3 upregulated the $\beta$-catenin expression, suggesting that MEG3 inhibits the invasiveness of GHPA cells by inactivating the $W n t / \beta$-catenin pathway.

Anterior pituitary with an epithelial phenotype expresses multiple cadherin proteins like E-cadherin that functions for cell attachment (Fougner et al., 2010). EMT is a vital mechanism underlying tumor cell invasion and metastasis. It has been well documented that the loss of E-cadherin and/or the increase of $\mathrm{N}$-cadherin are hallmarks of EMT $(27,28)$. In a variety of types of tumors, the $W n t / \beta$-catenin signaling pathway is constitutively active to promote EMT (Liang et al., 2017). The present study uncovered that $\beta$ catenin and EMT-related functional proteins are altered by MEG3 in GHPA tumors carrying the GNAS mutations. Accordingly, enforcedly elevated MEG3 in GHPA cells led to the upregulation of E-cadherin but downregulation of $\mathrm{N}$-cadherin, and Vimentin via altering $\beta$-catenin transcriptional regulation.

In addition, MMPs, the important proteolytic enzymes in the degradation of extracellular matrix and basement membrane, are crucial for tumor cell invasion (Di Nezza et al., 2002). Among of MMPs, MMP-2 and MMP-9 have been demonstrated to play vital roles in tumor invasion due to their potent ability to degrade collagen types IV (Scheau et al., 2019). In particular, their functions have been involved in the invasiveness of GHPA tumors (Yang and Li, 2019). Similar to other EMT-related proteins, our study further showed the levels of MMP-2 and MMP-9 decrease in GHPA tumors carrying the GNAS mutations, as well as the increase of MEG3 expression in GHPA cells resulted in decreasing the expression of MMP-2 and MMP-9, confirming the previous finding that MMPs participate in the progression of GHPA. Furthermore, how $M E G 3$ regulates $\beta$-catenin-mediated transcriptional activation is being currently investigated.

\section{Conclusions}

In summary, this study revealed that GNAS mutations inhibit the invasiveness of GHPA tumors by increasing the level of MEG3. The upregulation of MEG3 in GHPA cells supresses the cell invasion capacity through inhibiting the $W n t / \beta$-catenin signaling pathway. The silence of $M E G 3$ upregulates $\beta$ catenin and enhances EMT. The finding suggests that MEG3 may serve as a biomarker for the detection of GHPA phenotype and inhibition of the Wnt/ $\beta$-catenin signaling pathway may provide a useful therapeutic approach in the intervention of GHPA. 


\section{Abbreviations}

GHPA: Growth hormone-secreting pituitary adenoma, GNAS. a subunit of the stimulatory G protein, MEG3: maternally expressed 3, EMT: epithelial-to-mesenchymal transition, FACS: fluorescence-activated cell sorter, CCK-8: Cell Counting Kit-8 (tradename), MMP: matrix metalloproteinase, siRNA: small interfering RNA or short interfering RNA, WT: wild type.

\section{Declarations}

\section{Funding}

This work was supported by the Applied Basic Research Programs of Science and Technology Commission Foundation of Jiangsu Province (NO. BE2015684)

\section{Competing of interests}

The authors declare that they have no competing of interests.

\section{Availability of data and materials}

The datasets during and analysed during the current study available from the corresponding author on reasonable request.

\section{Code availability}

Not applicable

\section{Authors' contributions}

Chiyuan Ma conceived and designed the study. Chao Tang, Chunyu Zhong, Junhao Zhu, Jin Yang and Xiangming Cai performed the experiments. Chao Tang, Chunyu Zhong, Junhao Zhu interpreted and analyzed the data. Chao Tang, Chunyu Zhong and Yong Xu wrote and revised the manuscript. All authors have read and agreed the content of the manuscript.

\section{Ethics approval and consent to participate}

The animal experiments protocols were approved by the Institutional Animal Committee of Jinling Hospital.

\section{Consent for publication}

Not applicable

\section{Acknowledgements}


We thank Dr. Xun Zhang, the Neuroendocrine Unit, Massachusetts General Hospital and Harvard Medical School, Boston, MA, USA for his advice on the structure of this article.

\section{References}

1. BILLESTRUP, N., SWANSON, L. W. \& VALE, W. 1986. Growth hormone-releasing factor stimulates proliferation of somatotrophs in vitro. Proc Natl Acad Sci U S A, 83, 6854-7.

2. COLAO, A., FERONE, D., MARZULLO, P. \& LOMBARDI, G. 2004. Systemic complications of acromegaly: epidemiology, pathogenesis, and management. Endocr Rev, 25, 102-52.

3. COTTIER, J. P., DESTRIEUX, C., BRUNEREAU, L., BERTRAND, P., MOREAU, L., JAN, M. \& HERBRETEAU, D. 2000. Cavernous sinus invasion by pituitary adenoma: MR imaging. Radiology, 215, 463-9.

4. DI NEZZA, L. A., MISAJON, A., ZHANG, J., JOBLING, T., QUINN, M. A., OSTOR, A. G., NIE, G., LOPATA, A. \& SALAMONSEN, L. A. 2002. Presence of active gelatinases in endometrial carcinoma and correlation of matrix metalloproteinase expression with increasing tumor grade and invasion. Cancer, $94,1466-75$.

5. FOUGNER, S. L., LEKVA, T., BOROTA, O. C., HALD, J. K., BOLLERSLEV, J. \& BERG, J. P. 2010. The expression of E-cadherin in somatotroph pituitary adenomas is related to tumor size, invasiveness, and somatostatin analog response. J Clin Endocrinol Metab, 95, 2334-42.

6. GEJMAN, R., BATISTA, D. L., ZHONG, Y., ZHOU, Y., ZHANG, X., SWEARINGEN, B., STRATAKIS, C. A., HEDLEY-WHYTE, E. T. \& KLIBANSKI, A. 2008. Selective loss of MEG3 expression and intergenic differentially methylated region hypermethylation in the MEG3/DLK1 locus in human clinically nonfunctioning pituitary adenomas. J Clin Endocrinol Metab, 93, 4119-25.

7. GHAHHARI, N. M. \& BABASHAH, S. 2015. Interplay between microRNAs and WNT/beta-catenin signalling pathway regulates epithelial-mesenchymal transition in cancer. Eur $\mathrm{J}$ Cancer, 51, 1638-49.

8. GOTO, Y., KINOSHITA, M., OSHINO, S., ARITA, H., KITAMURA, T., OTSUKI, M., SHIMOMURA, I., YOSHIMINE, T. \& SAITOH, Y. 2014. Gsp mutation in acromegaly and its influence on TRH-induced paradoxical GH response. Clin Endocrinol (Oxf), 80, 714-9.

9. GUPTA, A., SCHULZE, T. G., NAGARAJAN, V., AKULA, N., CORONA, W., JIANG, X. Y., HUNTER, N., MCMAHON, F. J. \& DETERA-WADLEIGH, S. D. 2012. Interaction networks of lithium and valproate molecular targets reveal a striking enrichment of apoptosis functional clusters and neurotrophin signaling. Pharmacogenomics J, 12, 328-41.

10. HAYWARD, B. E., BARLIER, A., KORBONITS, M., GROSSMAN, A. B., JACQUET, P., ENJALBERT, A. \& BONTHRON, D. T. 2001. Imprinting of the G(s)alpha gene GNAS1 in the pathogenesis of acromegaly. J Clin Invest, 107, R31-6.

11. KATZNELSON, L., LAWS, E. R., JR., MELMED, S., MOLITCH, M. E., MURAD, M. H., UTZ, A., WASS, J. A. \& ENDOCRINE, S. 2014. Acromegaly: an endocrine society clinical practice guideline. J Clin Endocrinol Metab, 99, 3933-51. 
12. KNOSP, E., STEINER, E., KITZ, K. \& MATULA, C. 1993. Pituitary adenomas with invasion of the cavernous sinus space: a magnetic resonance imaging classification compared with surgical findings. Neurosurgery, 33, 610-7; discussion 617-8.

13. KRISHNAMURTHY, N. \& KURZROCK, R. 2018. Targeting the Wnt/beta-catenin pathway in cancer: Update on effectors and inhibitors. Cancer Treat Rev, 62, 50-60.

14. LANDIS, C. A., HARSH, G., LYONS, J., DAVIS, R. L., MCCORMICK, F. \& BOURNE, H. R. 1990. Clinical characteristics of acromegalic patients whose pituitary tumors contain mutant Gs protein. J Clin Endocrinol Metab, 71, 1416-20.

15. LANIA, A., MANTOVANI, G. \& SPADA, A. 2012. cAMP pathway and pituitary tumorigenesis. Ann Endocrinol (Paris), 73, 73-5.

16. LI, Q., LAI, Q., HE, C., FANG, Y., YAN, Q., ZHANG, Y., WANG, X., GU, C., WANG, Y., YE, L., HAN, L., LIN, X., CHEN, J., CAI, J., LI, A. \& LIU, S. 2019. RUNX1 promotes tumour metastasis by activating the Wnt/beta-catenin signalling pathway and EMT in colorectal cancer. J Exp Clin Cancer Res, 38, 334.

17. LIANG, Z., LU, L., MAO, J., LI, X., QIAN, H. \& XU, W. 2017. Curcumin reversed chronic tobacco smoke exposure induced urocystic EMT and acquisition of cancer stem cells properties via Wnt/betacatenin. Cell Death Dis, 8, e3066.

18. MA, J., LI, T. F., HAN, X. W. \& YUAN, H. F. 2019. Downregulated MEG3 contributes to tumour progression and poor prognosis in oesophagal squamous cell carcinoma by interacting with miR4261, downregulating DKK2 and activating the Wnt/beta-catenin signalling. Artif Cells Nanomed Biotechnol, 47, 1513-1523.

19. MANTOVANI, G., LANIA, A. G. \& SPADA, A. 2010. GNAS imprinting and pituitary tumors. Mol Cell Endocrinol, 326, 15-8.

20. MELMED, S. 2006. Medical progress: Acromegaly. N Engl J Med, 355, 2558-73.

21. NIEHRS, C. 2006. Function and biological roles of the Dickkopf family of Wnt modulators. Oncogene, 25, 7469-81.

22. NUSSE, R. \& CLEVERS, H. 2017. Wnt/beta-Catenin Signaling, Disease, and Emerging Therapeutic Modalities. Cell, 169, 985-999.

23. ORME, S. M., MCNALLY, R. J., CARTWRIGHT, R. A. \& BELCHETZ, P. E. 1998. Mortality and cancer incidence in acromegaly: a retrospective cohort study. United Kingdom Acromegaly Study Group. J Clin Endocrinol Metab, 83, 2730-4.

24. SCHEAU, C., BADARAU, I. A., COSTACHE, R., CARUNTU, C., MIHAI, G. L., DIDILESCU, A. C., CONSTANTIN, C. \& NEAGU, M. 2019. The Role of Matrix Metalloproteinases in the EpithelialMesenchymal Transition of Hepatocellular Carcinoma. Anal Cell Pathol (Amst), 2019, 9423907.

25. SPADA, A., AROSIO, M., BASSETTI, M., VALLAR, L., CLEMENTI, E. \& BAZZONI, N. 1991. Mutations in the alpha subunit of the stimulatory regulatory protein of adenylyl cyclase (Gs) in human $\mathrm{GH}$ secreting pituitary adenomas. Biochemical, clinical, and morphological aspects. Pathol Res Pract, $187,567-70$. 
26. SPADA, A., AROSIO, M., BOCHICCHIO, D., BAZZONI, N., VALLAR, L., BASSETTI, M. \& FAGLIA, G. 1990. Clinical, biochemical, and morphological correlates in patients bearing growth hormone-secreting pituitary tumors with or without constitutively active adenylyl cyclase. J Clin Endocrinol Metab, 71, 1421-6.

27. STORK, P. J. \& SCHMITT, J. M. 2002. Crosstalk between cAMP and MAP kinase signaling in the regulation of cell proliferation. Trends Cell Biol, 12, 258-66.

28. WILSON, T. J., MCKEAN, E. L., BARKAN, A. L., CHANDLER, W. F. \& SULLIVAN, S. E. 2013. Repeat endoscopic transsphenoidal surgery for acromegaly: remission and complications. Pituitary, 16, 459 -64 .

29. YAMAMOTO, K. K., GONZALEZ, G. A., MENZEL, P., RIVIER, J. \& MONTMINY, M. R. 1990. Characterization of a bipartite activator domain in transcription factor CREB. Cell, 60, 611-7.

30. YANG, Q. \& LI, X. 2019. Molecular Network Basis of Invasive Pituitary Adenoma: A Review. Front Endocrinol (Lausanne), 10, 7.

31. ZHANG, J., HE, L., YANG, Z., LI, L. \& CAI, W. 2019. Lithium chloride promotes proliferation of neural stem cells in vitro, possibly by triggering the Wnt signaling pathway. Anim Cells Syst (Seoul), 23, 3241.

32. ZHANG, X., GEJMAN, R., MAHTA, A., ZHONG, Y., RICE, K. A., ZHOU, Y., CHEUNSUCHON, P., LOUIS, D. N. \& KLIBANSKI, A. 2010. Maternally expressed gene 3 , an imprinted noncoding RNA gene, is associated with meningioma pathogenesis and progression. Cancer Res, 70, 2350-8.

33. ZHANG, X., ZHOU, Y., MEHTA, K. R., DANILA, D. C., SCOLAVINO, S., JOHNSON, S. R. \& KLIBANSKI, A. 2003. A pituitary-derived MEG3 isoform functions as a growth suppressor in tumor cells. J Clin Endocrinol Metab, 88, 5119-26.

34. ZHAO, J., ZHANG, X., ZHOU, Y., ANSELL, P. J. \& KLIBANSKI, A. 2006. Cyclic AMP stimulates MEG3 gene expression in cells through a cAMP-response element (CRE) in the MEG3 proximal promoter region. Int J Biochem Cell Biol, 38, 1808-20.

35. ZHUANG, X., ZHANG, H., LI, X., LI, X., CONG, M., PENG, F., YU, J., ZHANG, X., YANG, Q. \& HU, G. 2017. Differential effects on lung and bone metastasis of breast cancer by Wnt signalling inhibitor DKK1. Nat Cell Biol, 19, 1274-1285.

\section{Tables}

Table 1 Comparison of clinical characteristics of patients with and without GNAS mutations 


\begin{tabular}{lccc}
\hline & GNAS-MUT & GNAS-WT & P value \\
\hline Patients(n) & $16(36.4 \%)$ & $28(63.6 \%)$ & \\
Age(yr) & $49.7 \pm 9.7$ & $47.5 \pm 10.1$ & 0.155 \\
Sex(male/female) & $10 / 6$ & $11 / 17$ & 0.138 \\
Volume $\left(\mathrm{mm}^{3}\right)$ & $4901.3 \pm 4212.7$ & $6861.9 \pm 3751.4$ & 0.003 \\
Knosp grade $(\%)$ & & & 0.001 \\
$0-2$ & $81.3 \%(13 / 16)$ & $28.6 \%(8 / 28)$ & \\
$3-4$ & $18.7 \%(3 / 16)$ & $71.4 \%(20 / 28)$ & \\
& & & \\
\hline
\end{tabular}

Table 2: The primer sequences of PCR and DNA sequencing

\begin{tabular}{|ll|}
\hline Gene & Primer sequences \\
\hline GNAS codon 227 & F: ATCATGGTTTCTTGACATTCACCCC \\
& R: CCACCACGAAGATGATGGCAGTC \\
\hline GNAS codon 201 & F: CAAGCAGGCTGACTATGTGCCGA \\
& R: GCTGGCCACCCACGTCAAAC \\
\hline FEG3 & F: ATCATCCGTCCACCTCCTTGTCTTC \\
\hline b-actin & F: CACCCAGCACAATGAAGATCAAGAT \\
& R: CCAGTTTTTAAATCCTGAGTCAAGC \\
\hline
\end{tabular}

Figures 
A
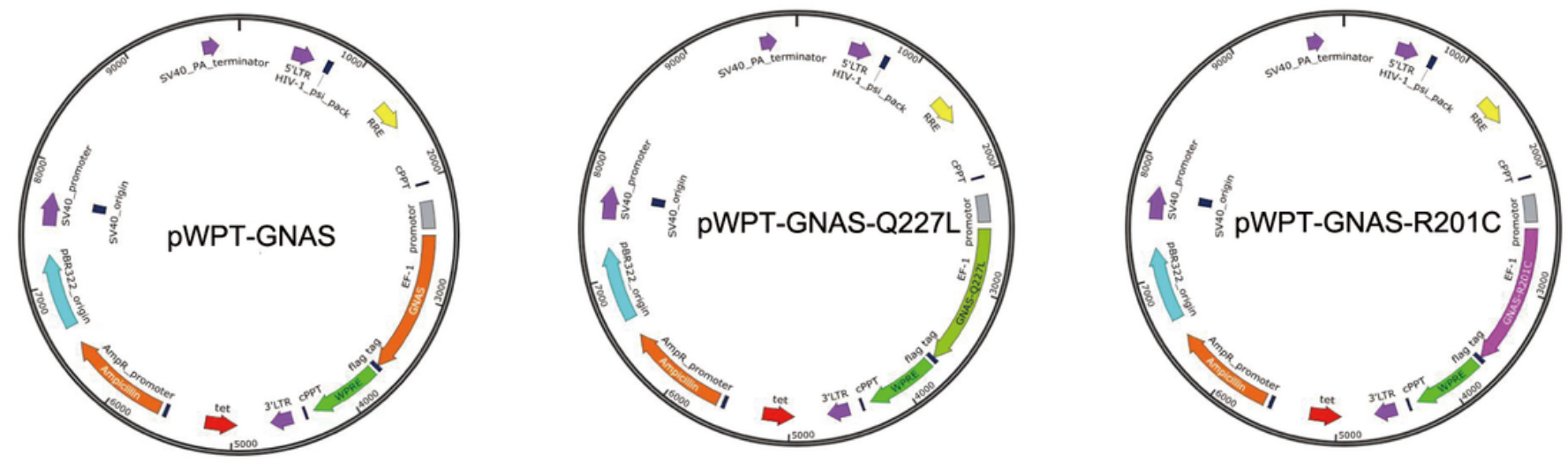

B

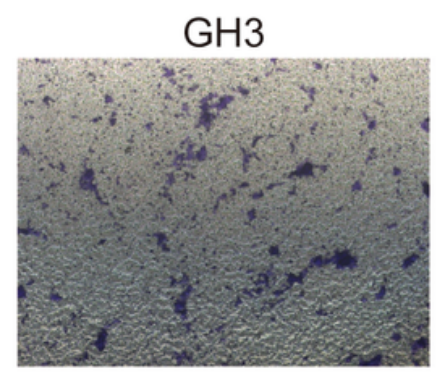

GH3-GNAS-WT
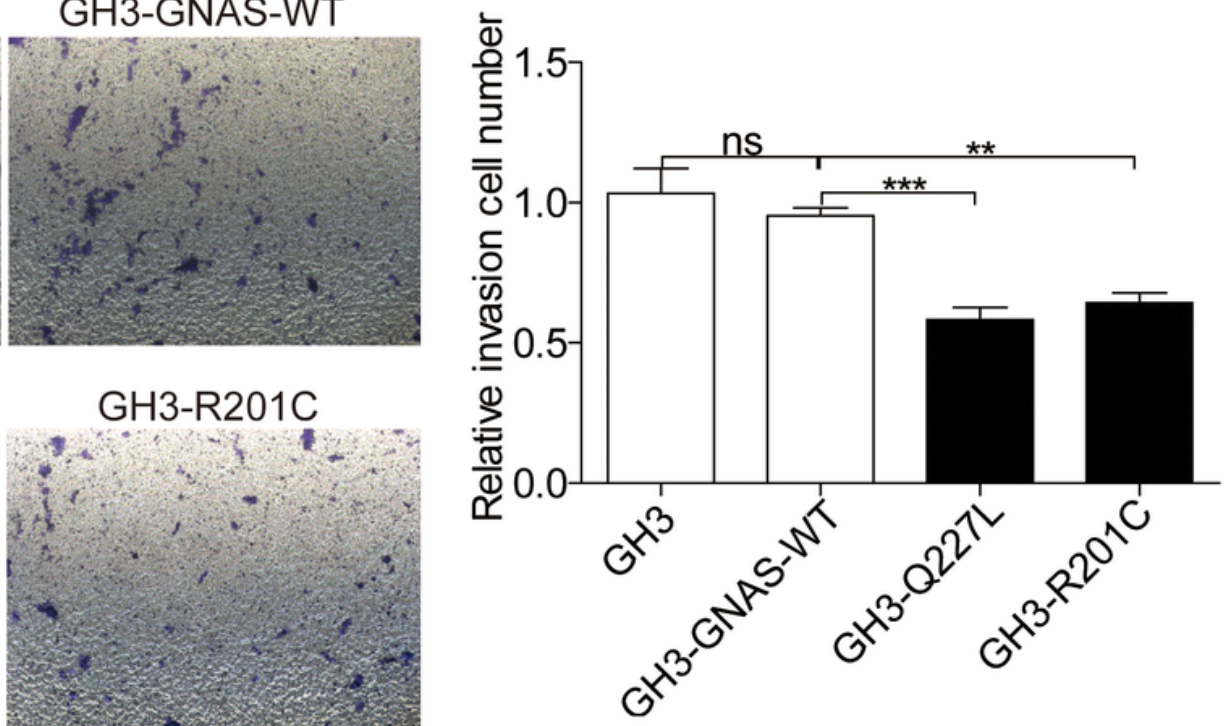

C

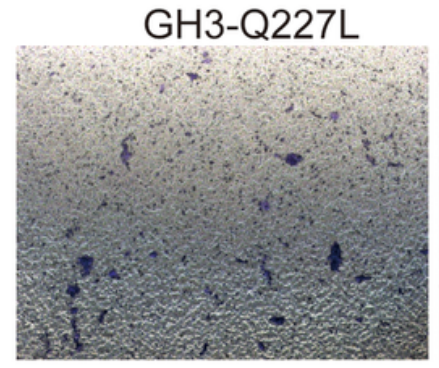

GH3-R201C
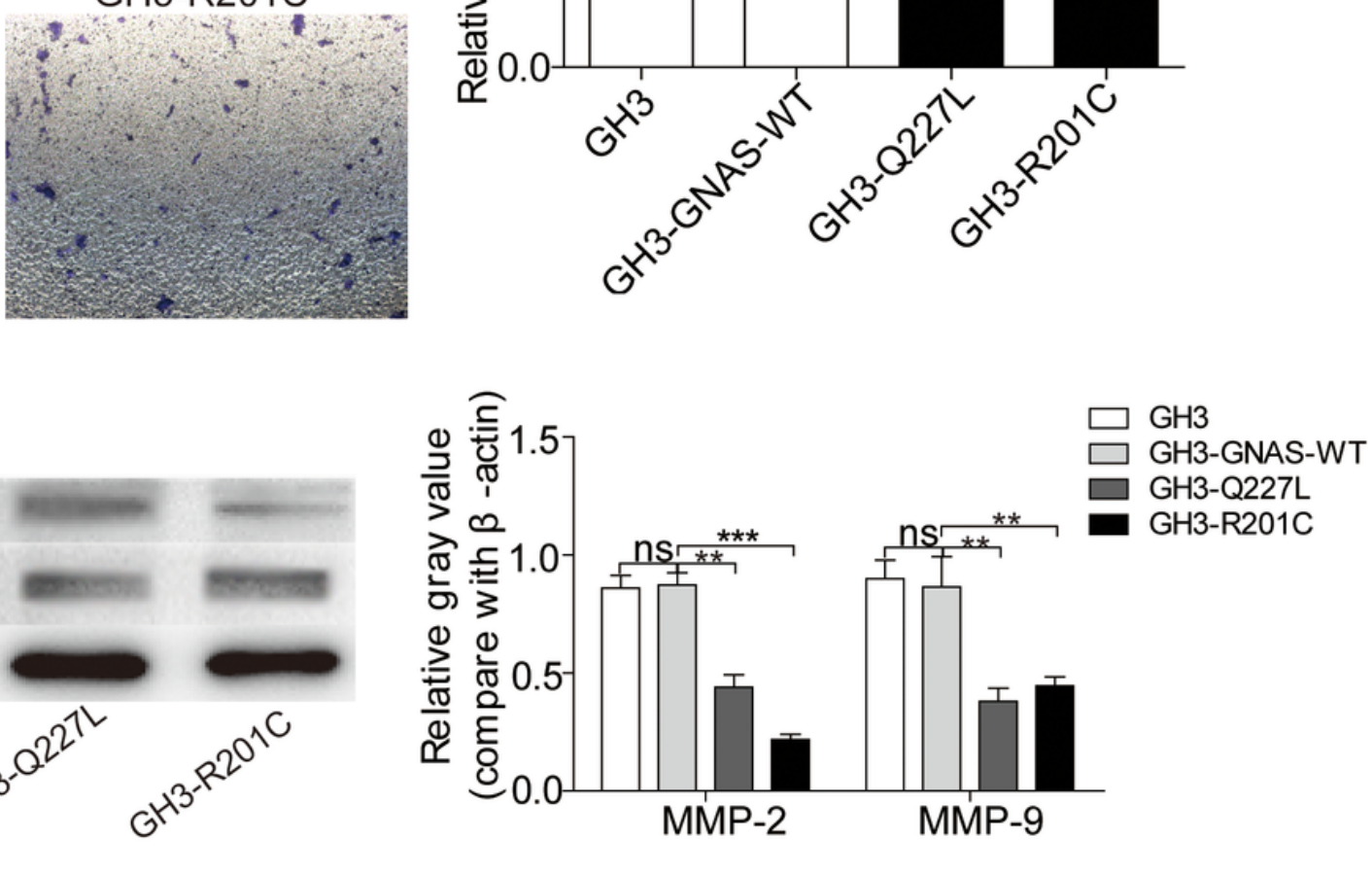

Figure 1

The GNAS mutations inhibit the GH3 cells invasion. A: The wild-type and mutant GNAS gene were expressed in GH3 cells by transduction with lentiviral vectors: pWPT-GNAS-Q227L, pWPT-GNAS-R201C and pWPT-GNAS. B: The cell invasion capacity was measured using a Transwell assay. C: The levels of MMP-2 and MMP-9 were quantified by Western blot. ${ }^{\star *}(p<0.01),{ }^{* \star *}(p<0.001)$ show the significances between the two groups as indicated, and "ns" shows no significances. 
A

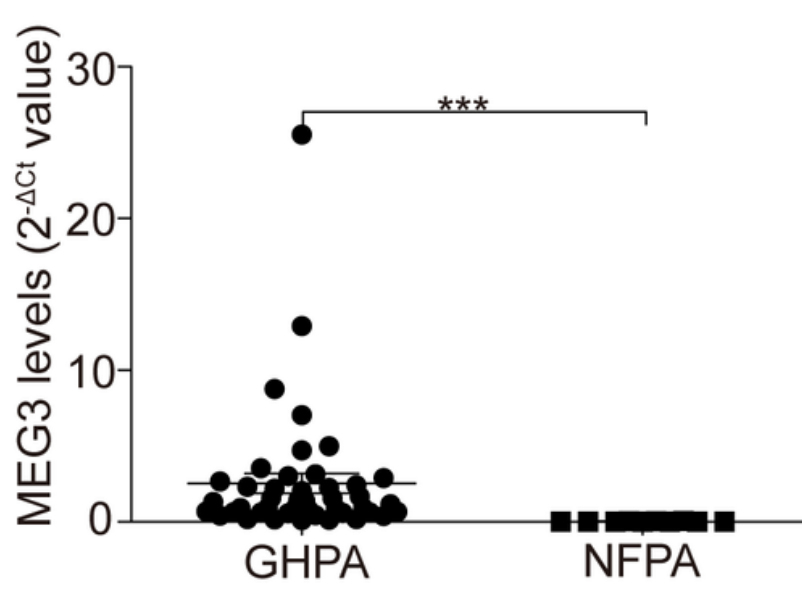

C

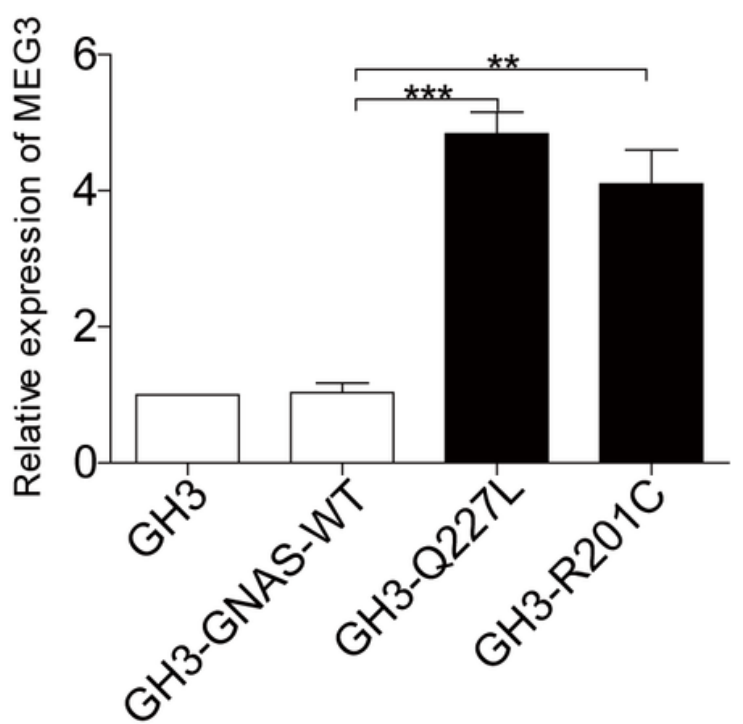

B

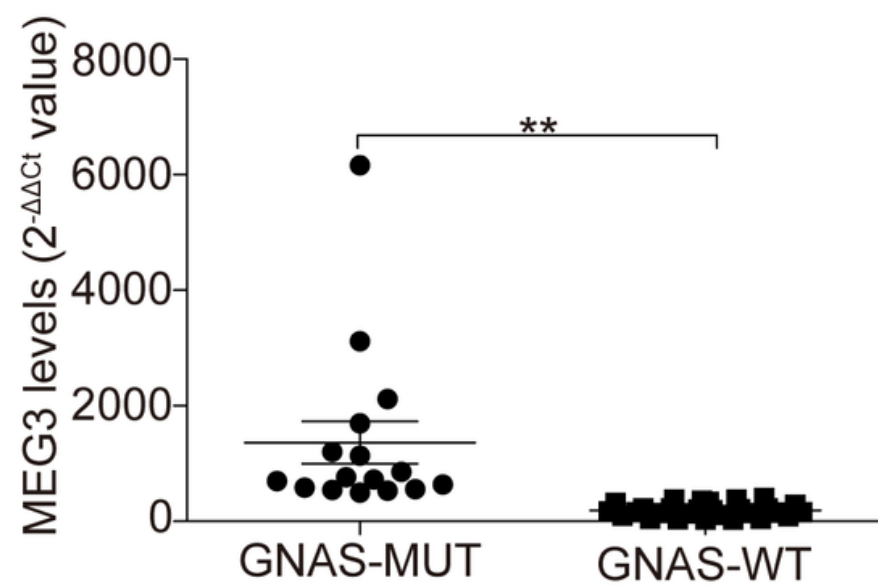

$\mathrm{D}$

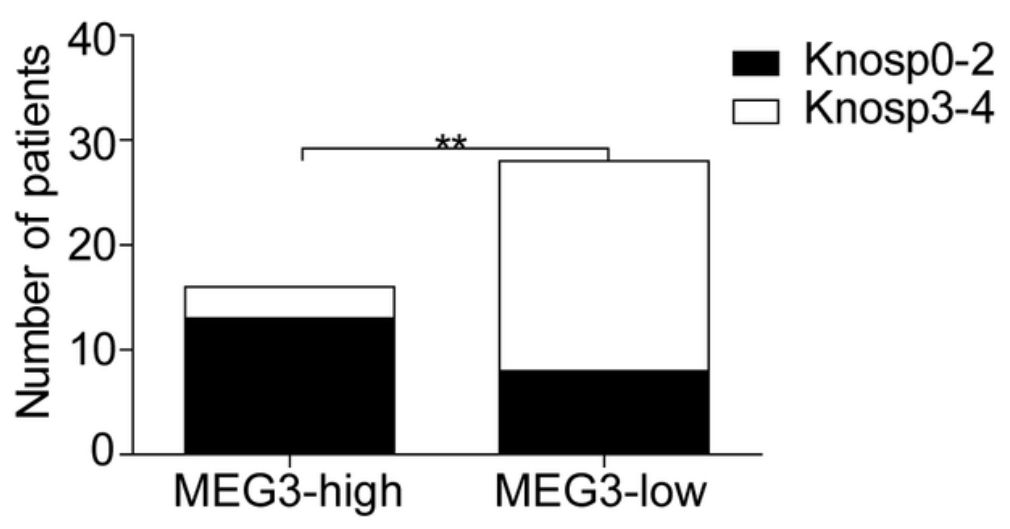

Figure 2

The GNAS mutations upregulate MEG3 expression. A: The expression of MEG3 in GHPA and NFPA was quantified by RT-qPCR analysis. B and C: The correlation between MEG3 expression and the GNAS mutations were determined by RT-qPCR analysis. D: The correlation between MEG3 expression and the percentage of invasive tumors was analyzed. ${ }^{\star}(p<0.01), * \star *(p<0.001)$ show the significances between the two groups as indicated. 
A
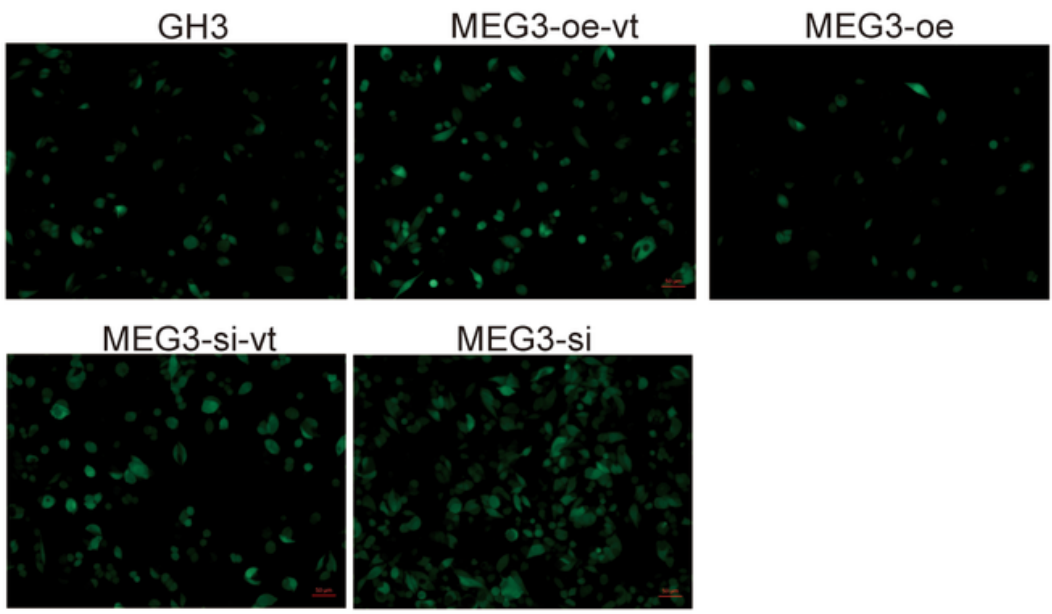

MEG3-si

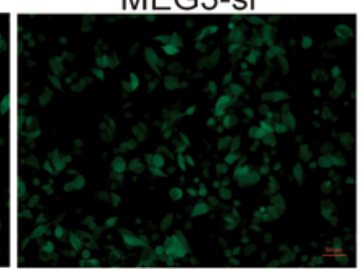

B

$\mathrm{GH} 3$

MEG3-oe-vt
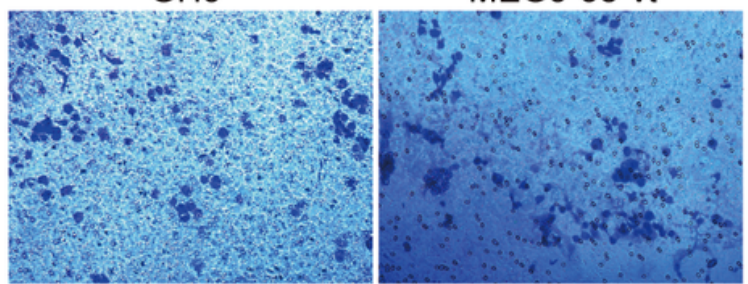

MEG3-oe

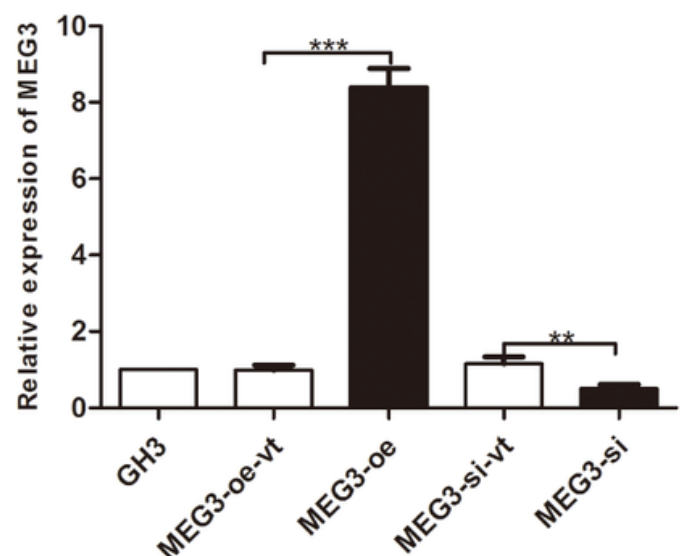

C
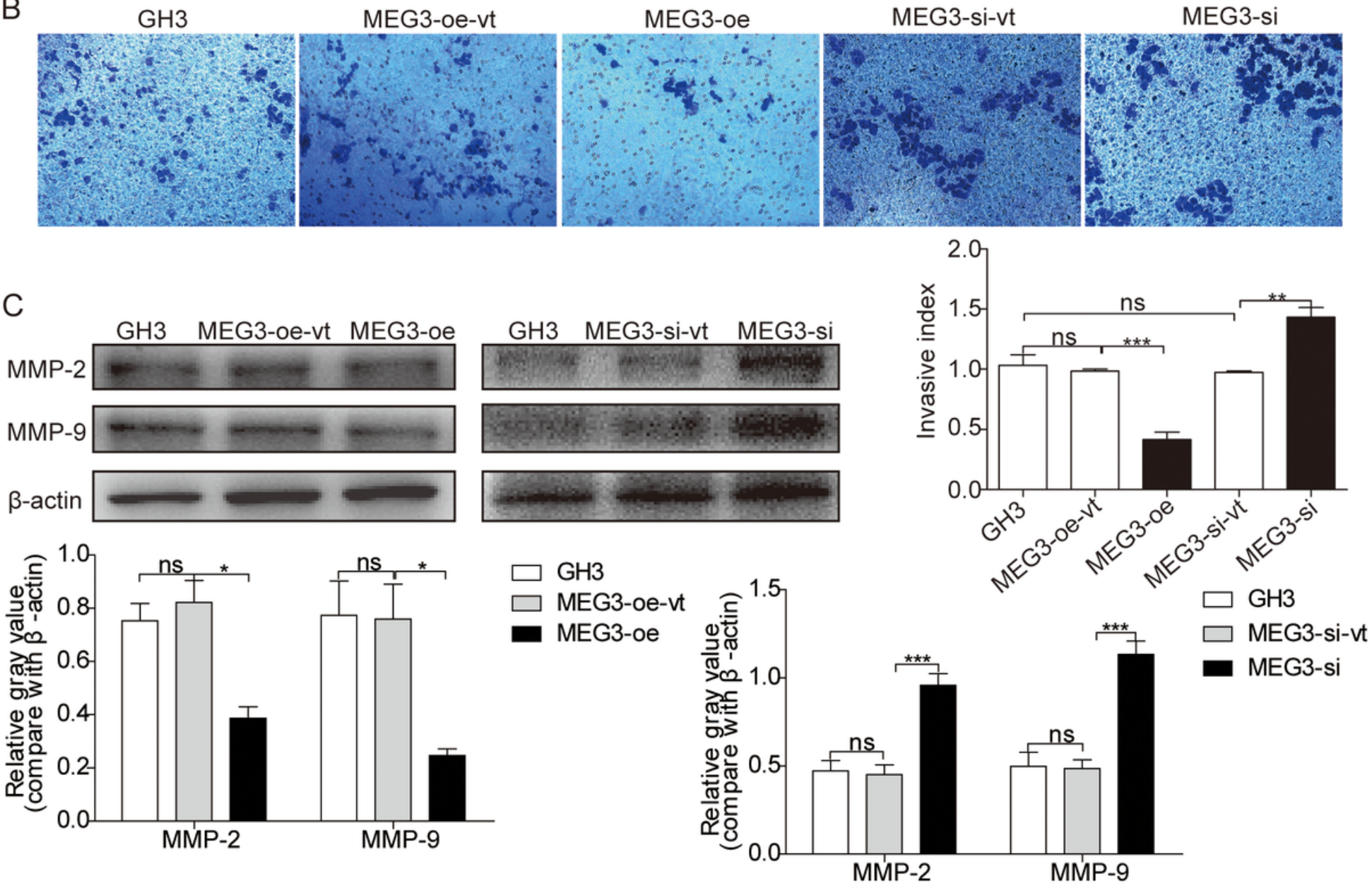

Figure 3

MEG3 inhibits the invasiveness of GHPA cells. A: MEG3 was overexpressed or knocked down in GH3 cells. The relative levels of MEG3 were quantified by immunofluorescence assay and confirmed by RTqPCR. B: The cell invasion was analyzed using a Transwell assay. C: The expression levels of MMP-2 and MMP-9 in MEG3-overexpressed cells were measured by Western blot. $*(p<0.05),{ }^{* *}(p<0.01), * \star *(p<$ 0.001 ) show the significances between the two groups as indicated, and "ns" shows no significances. 
A

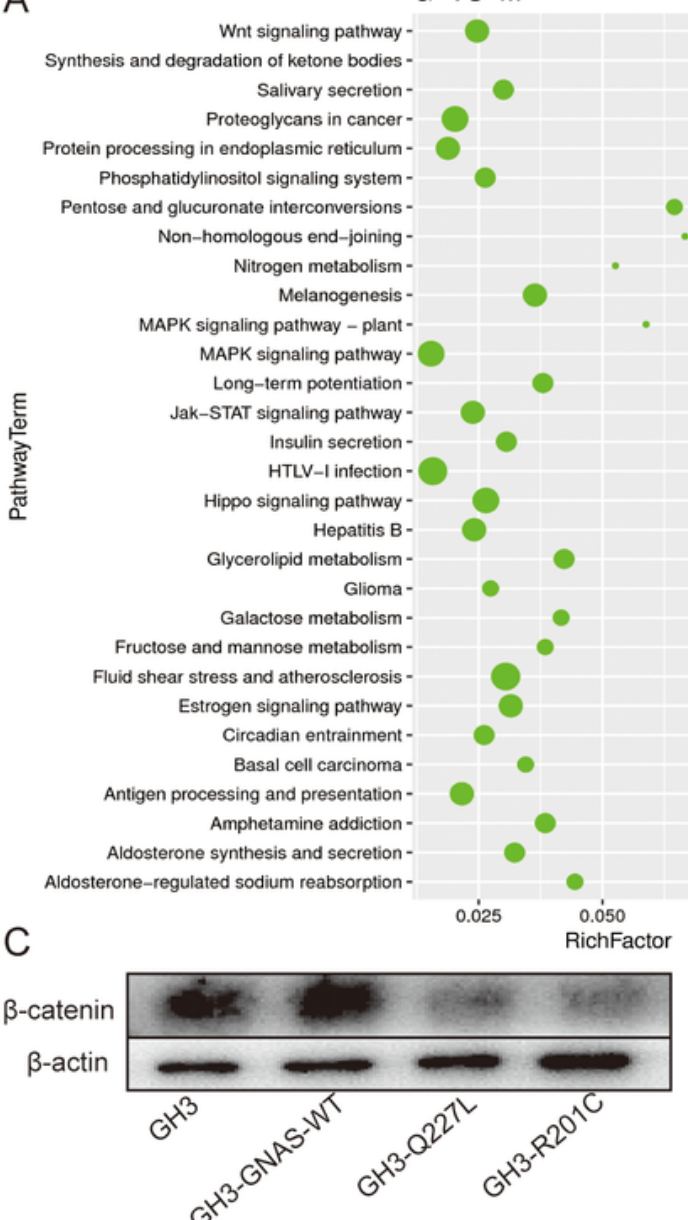

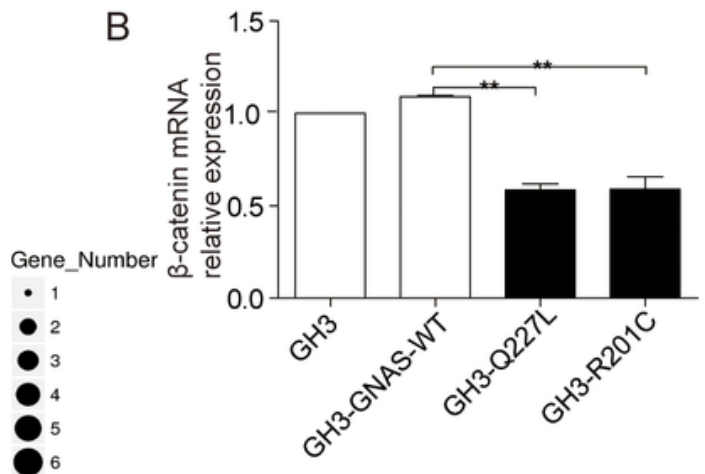

0.075
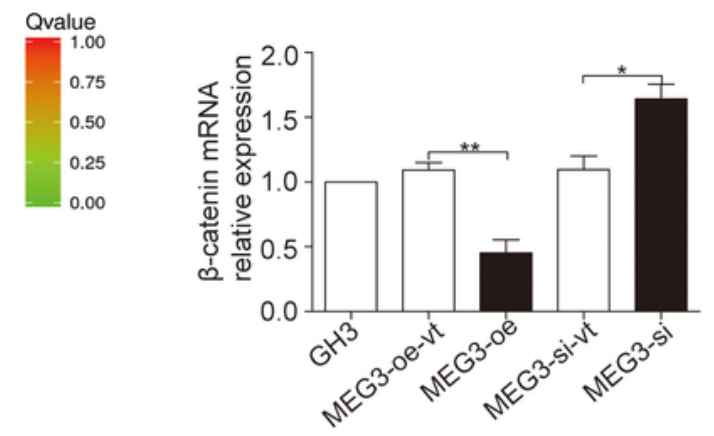
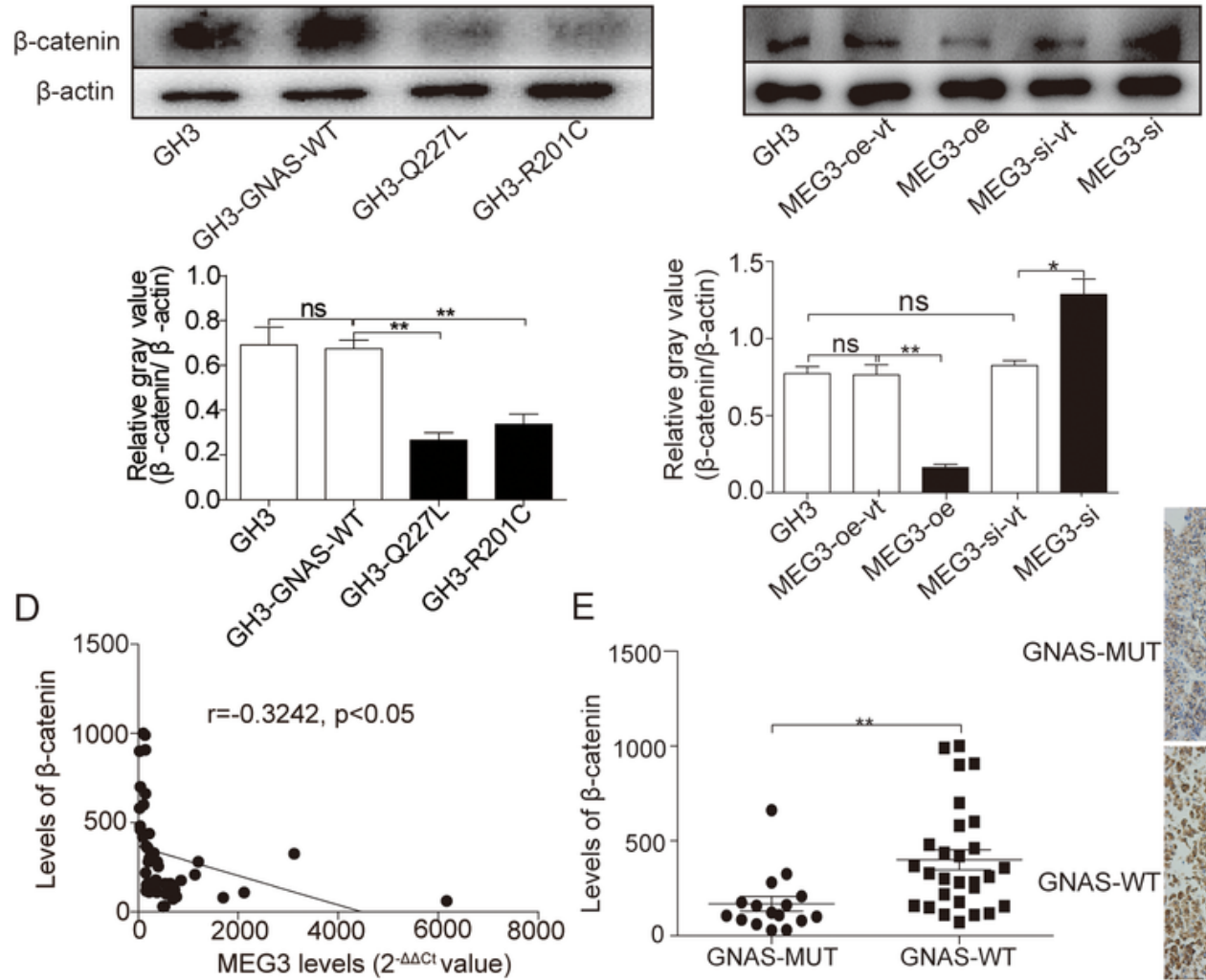

E
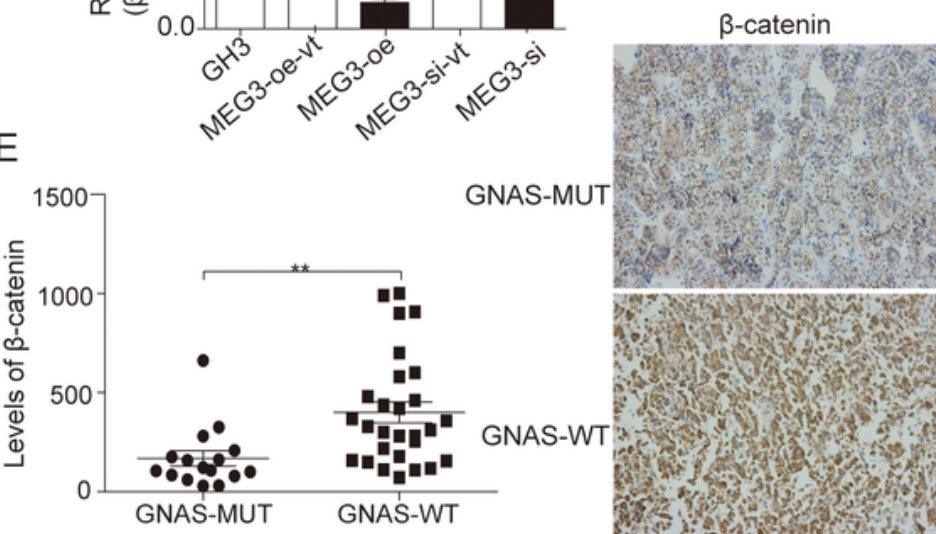

Figure 4

MEG3 inhibits the invasiveness of GHPA with the GNAS mutations by inactivating the Wnt/ $\beta$-catenin signaling pathway.

A: RNA-seq was used to examine the gene expression profiles in MEG3-overexpressed GH3 cells compared to vector-only control. The altered mRNA expression profile was analyzed using KEGG pathway 
enrichment. B: The reduction of $\beta$-catenin mRNA expression in GHPA tumors with the GNAS mutations or $\mathrm{GH} 3$ cells with a high level of MEG3 was confirmed by RT-qPCR. C: The relative $\beta$-catenin protein levels were measured by Western blot. D and E: The correlation between MEG3 and the $\beta$-catenin protein levels was analyzed RT-qPCR and IHC. * $(p<0.05),{ }^{*}(p<0.01)$ show the significances between the two groups as indicated.

A
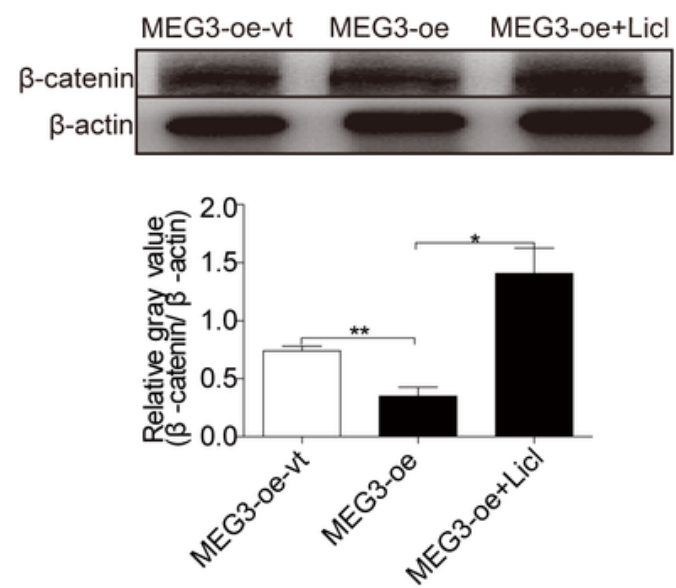
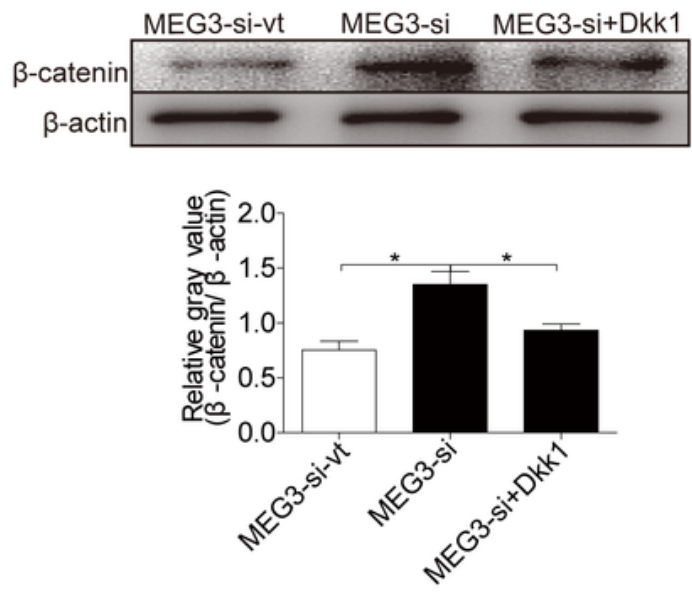

в
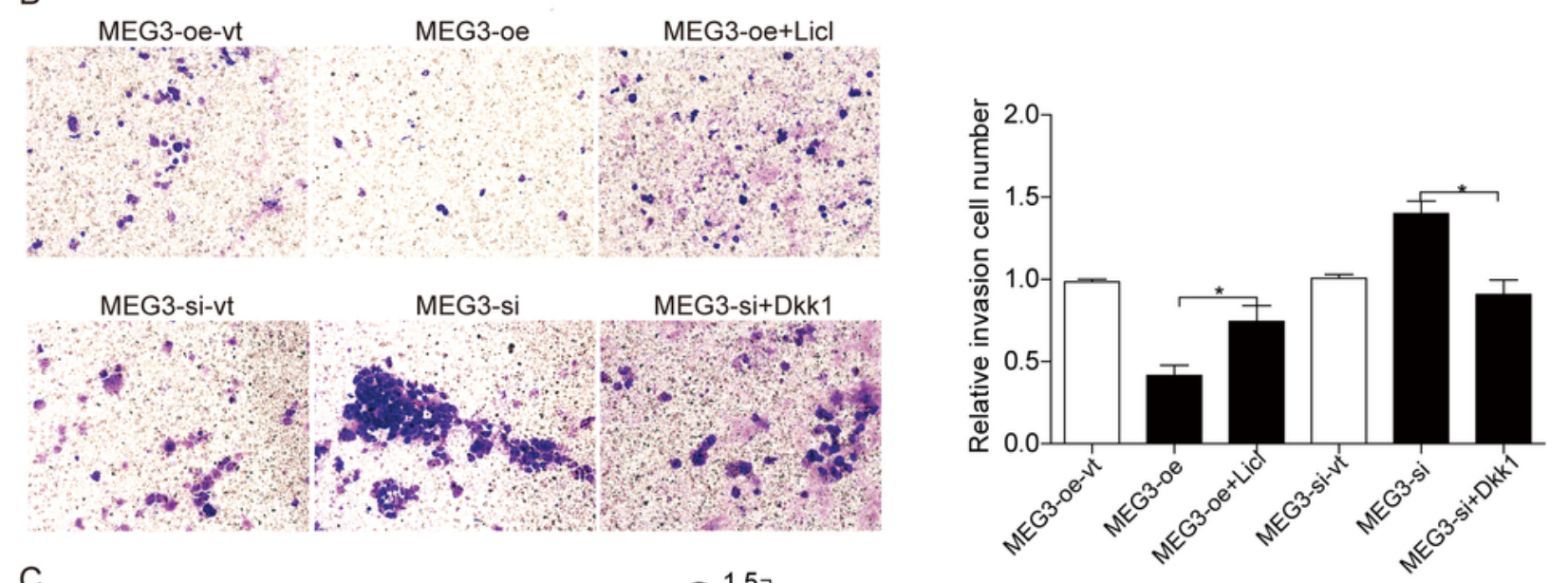

C
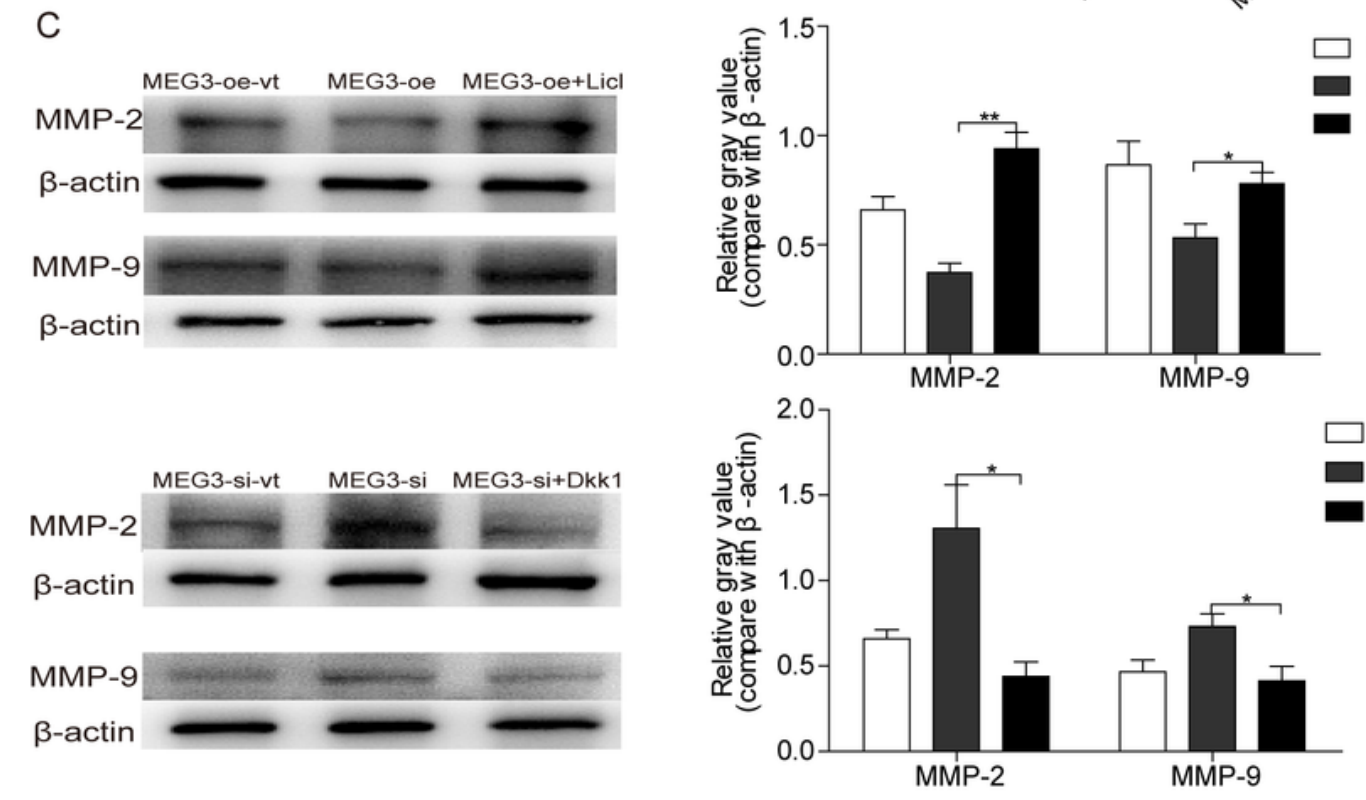

Figure 5 
MEG3-mediated downregulated $\beta$-catenin inhibits the invasion of GH3 cells.

A: MEG3 was manipulated by expressing or silencing MEG3 in GH3 cells. In addition, the expression of $\beta$ catenin was induced by Licl or repressed by Dkk1. The level of $\beta$-catenin in the MEG3-manipulated GH3 cells was measured using Western blot. B: The relative cell invasion was quantified by Transwell assay. C: The expression of MMP-2 and MMP-9 was also measured using Western blot. ${ }^{*}(p<0.05), * *(p<0.01)$ show the significances between the two groups as indicated.
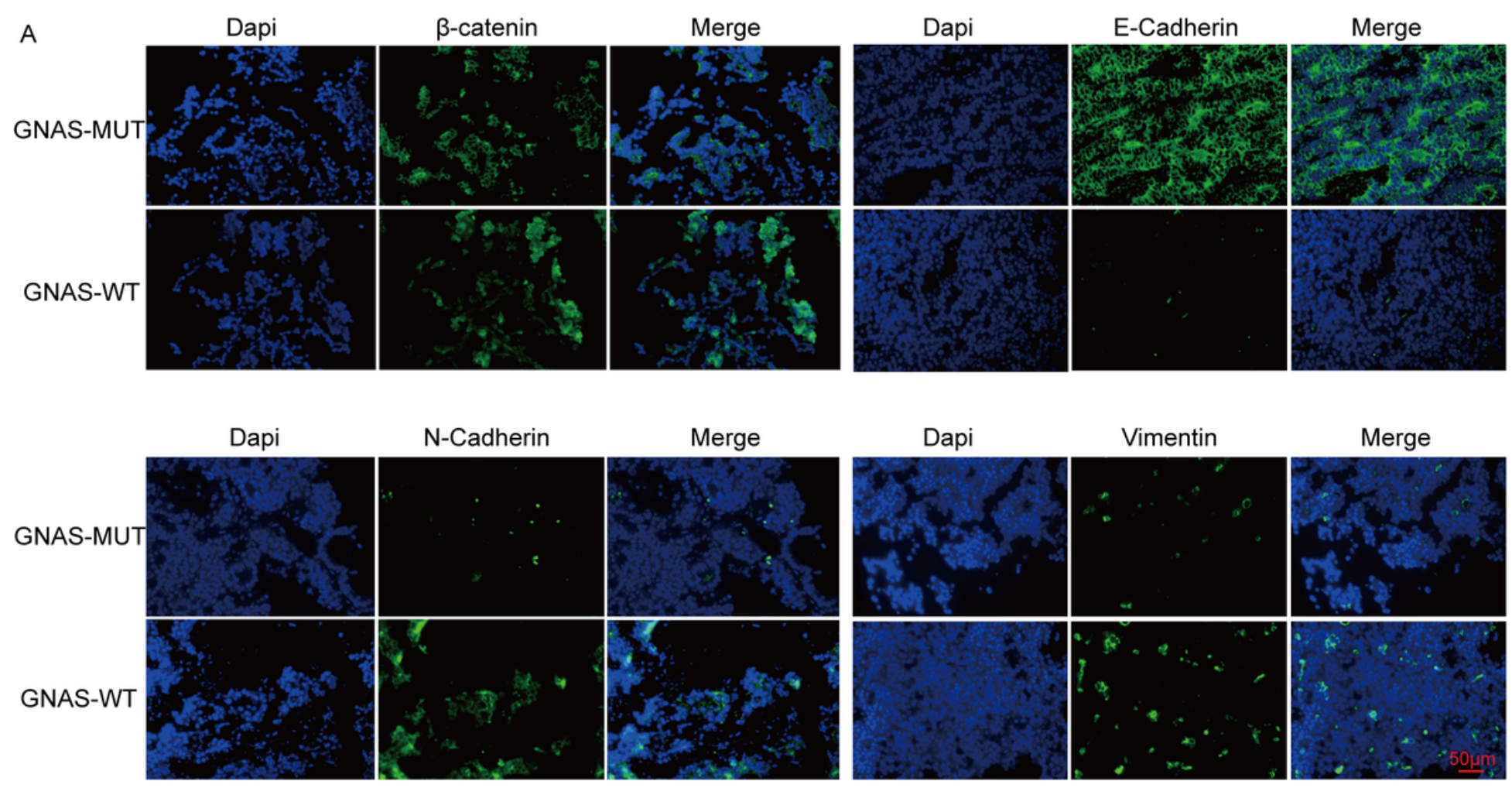

B

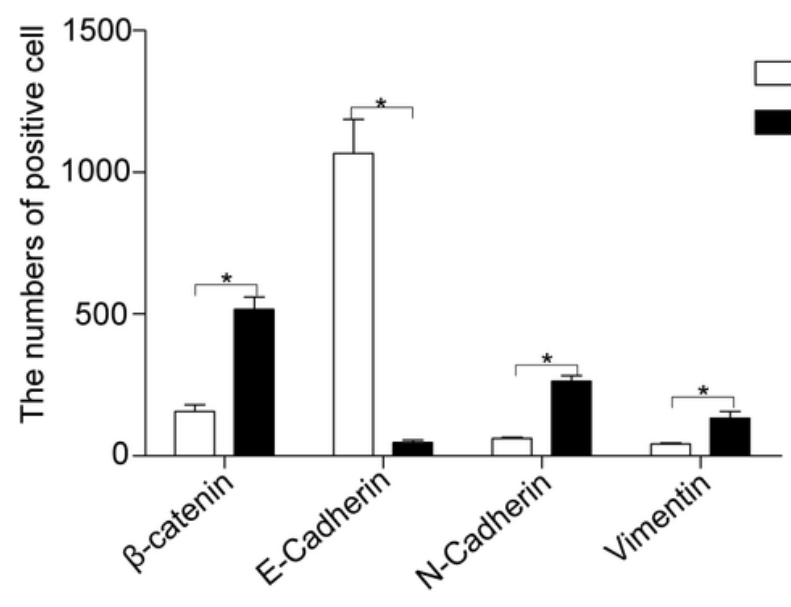

C 
suggested mechanism underlying the GNAS mutations inhibiting the invasiveness of GHPA.

A

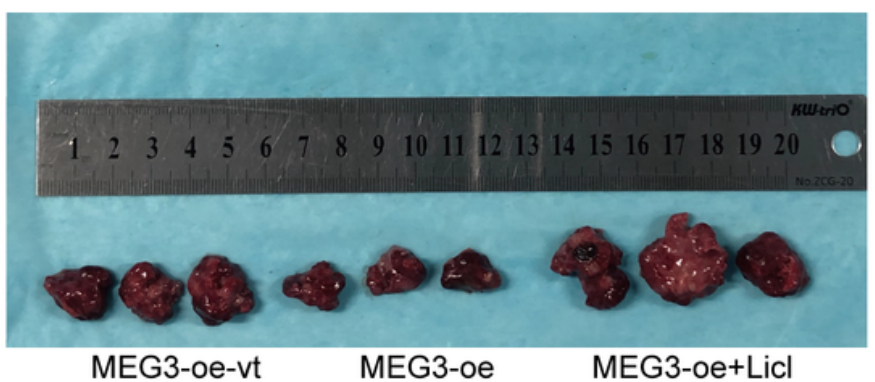

D

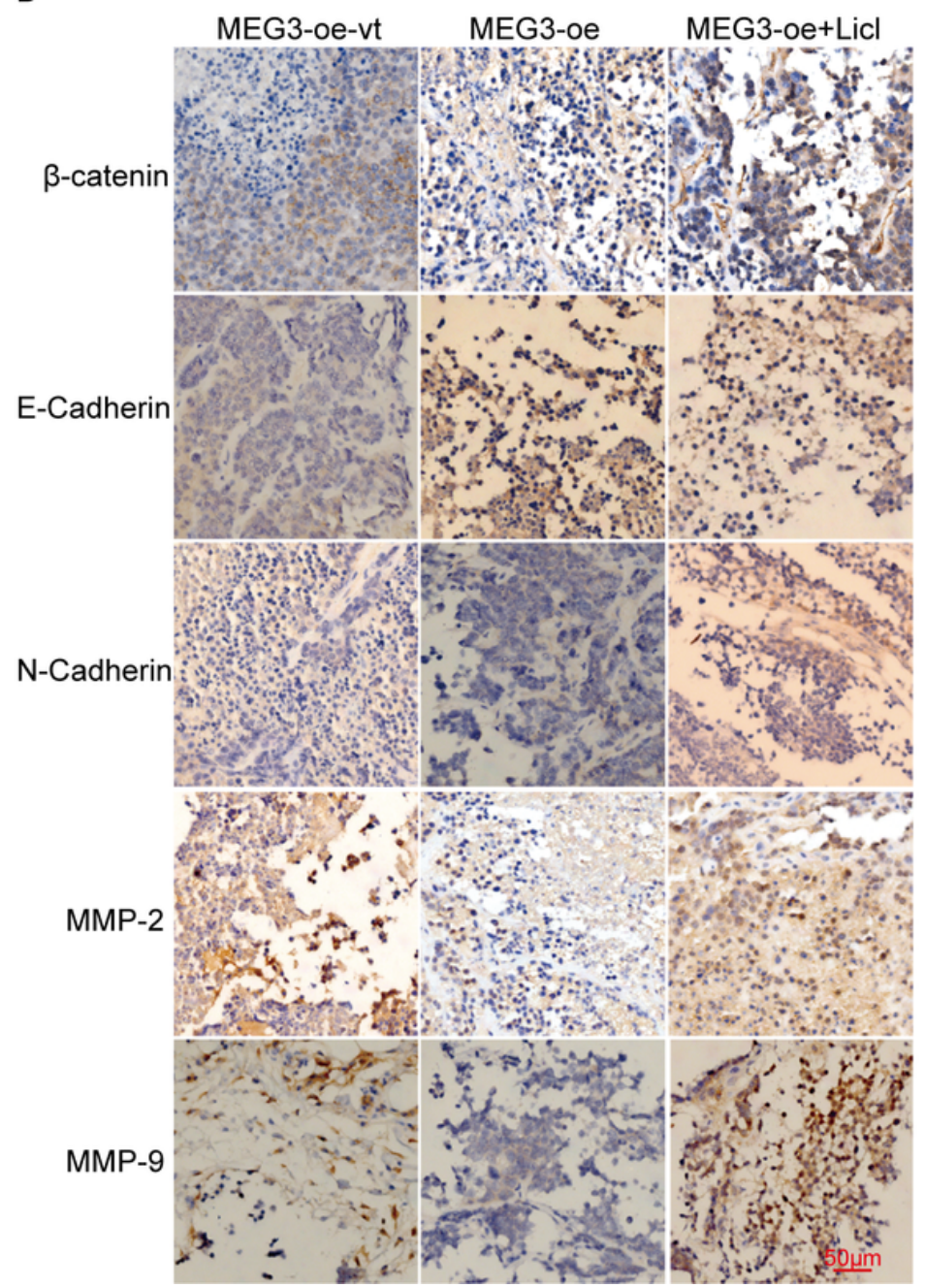

B

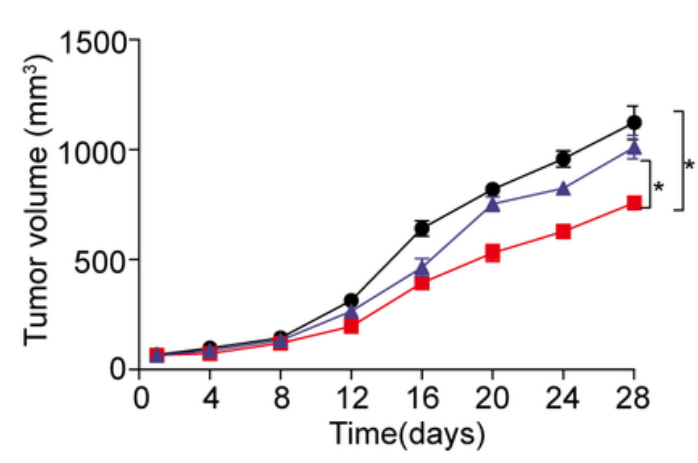

- MEG3-oe+Licl

- MEG3-oe

—-MEG3-oe-vt

C

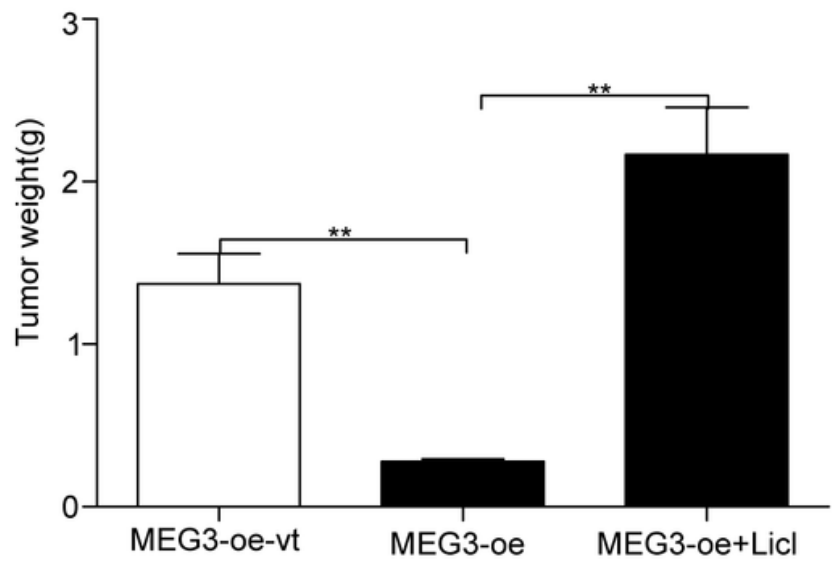

E

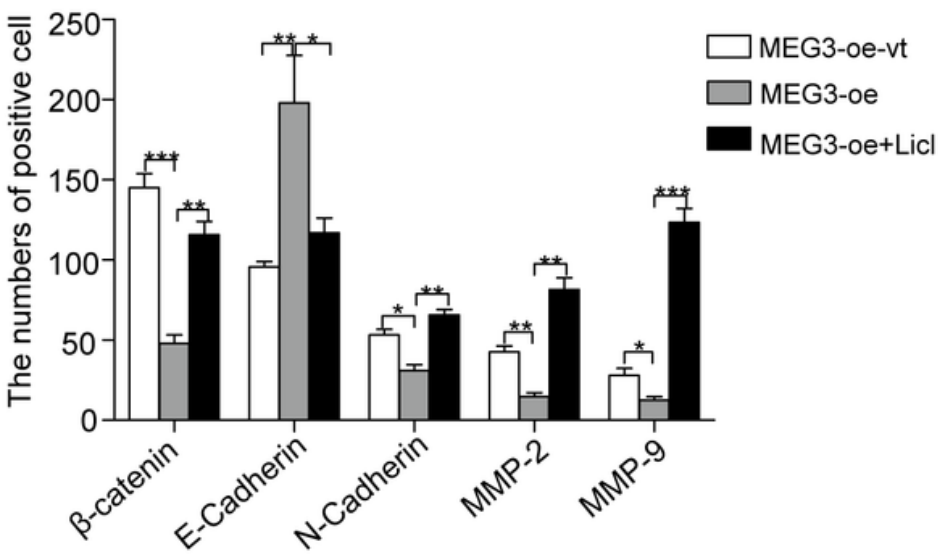

Figure 7

\section{MEG3 inhibits the GHPA cell invasion in vivo.}

A-C: GH3 cell lines with different levels of MEG3 were subcutaneously injected into null mice and followed by Licl treatment. The excised tumors were photographed and the tumor volume and weight in each group were measured. D: The levels of $\beta$-catenin, E-cadherin, N-cadherin, MMP-2, and MMP-9 in 
tumor tissues were quantified by IHC (magnification, $x 200) . *(p<0.05), * \star(p<0.01), * \star \star(p<0.001)$ show the significances between the two groups as indicated. 